\title{
ANALISIS HAK MEWARIS ANAK YANG LAHIR DARI PERKAWINAN BEDA AGAMA
}

\author{
Hasnan Hasbi \\ Dosen Fakultas Hukum Universitas Muslim Indonesia Makassar \\ email : hasnan.hasbi@gmail.com
}

\begin{abstract}
Interfaith marriage has no right to obtain the estate when faith is different from that in this case the heir to the heir to the Muslims. However, when the beneficiary is not a Muslim (non-Muslims), and their heirs and successors religion (non-Muslim), they are still entitled to inherit. It is based on blood relationship between the heir to the heir, as provided for in Article 832 of the Civil Code and Article 171 c Compilation of Islamic Law (KHI), while the factors that impede the rights of inheritance of children born of interfaith marriage is not the unification of the governing the beneficiary because in reality there is pluralism of inheritance law, so that problem solving inheritance rights of children born out of wedlock different religions each party subject to different laws are based on religious or customary law.
\end{abstract}

Keywords: Right inheriting; interfaith marriage;

\begin{abstract}
Abstrak
Perkawinan beda agama tidak memiliki hak untuk mendapatkan harta warisan ketika iman berbeda dari yang dalam hal ini pewaris pewaris untuk umat Islam. Namun, ketika penerima manfaat bukan Muslim (non-Muslim), dan ahli waris dan penggantinya agama (non-Muslim), mereka masih berhak mewarisi. Hal ini didasarkan pada hubungan darah antara ahli waris dengan ahli waris, sebagaimana diatur dalam Pasal 832 KUH Perdata dan Pasal 171 c Kompilasi Hukum Islam (KHI), sedangkan faktor-faktor yang menghambat hak-hak warisan anak-anak yang lahir dari pernikahan beda agama. bukan penyatuan pemerintahan penerima karena pada kenyataannya ada pluralisme hukum waris, sehingga penyelesaian masalah hak waris anak-anak yang lahir di luar nikah agama yang berbeda masing-masing pihak yang tunduk pada hukum yang berbeda berdasarkan hukum agama atau hukum adat.
\end{abstract}

Kata kunci: Hak Waris; Pernikahan; Beda Agama

\section{A. PENDAHULUAN}

Perkawinan merupakan suatu kejadian yang sangat penting bagi kehidupan setiap orang, karena suatu ritual perkawinan kadang tidak hanya dipandang sebagai peristiwa sosial keduniawian, melainkan juga dipandang sebagai peristiwa sakral yang dipengaruhi alam pikiran magis berdasarkan kepercayaan masing-masing.

Vol. 20 No. 1 Mei 2018 
Setiap manusia pasti mendambakan yang namanya perkawinan, baik itu pria maupun wanita karena manusia diciptakan untuk berpasang-pasangan. Karena dipandang perkawinan adalah sesuatu yang sakral sehingga setiap orang terkadang harus berfikir seribu kali dalam mempersiapkannya. Perkawinan tidak saja menyangkut kedua calon suami istri tetapi juga menyangkut urusan keluarga dan masyarakat. Pada umumnya perkawinan dianggap sebagai sesuatu yang suci dan karenanya setiap agama selalu menghubungkan kaedah-kaedah perkawinan dengan kaedah-kaedah agama.

Dalam peristiwa perkawinan diperlukan norma hukum dan tata tertib yang mengaturnya. Penerapan norma hukum dalam peristiwa perkawinan terutama diperlukan dalam rangka mengatur hak, kewajiban, dan tanggungjawab masing-masing kedua pihak dan anggota keluarga, guna membentuk rumah tangga yang bahagia dan sejahtera. Sejak dilangsungkan perkawinan akan timbul ikatan lahir bathin antara kedua mempelai dan juga timbul hubungan kekeluargaan di antara kerabat kedua pihak.

Perkawinan juga sering dikatakan sebagai awal terbentuknya keluarga yang baru, yang dimana seorang suami bertanggung jawab atas istri dan istri juga bertanggung jawab untuk menjaga kehormatan suami dan keluarga yang mereka bina. Mengingat pentingnya perkawinan ini, negara indonesia sebagai bangsa yang berdaulat dan negara hukum maka pemerintah mengaturnya dengan dikeluarkannya Undang-Undang Nomor 1 Tahun 1974 tentang Perkawinan yang berlaku efektif tanggal 1 Oktober 1975 dan ketentuan pelaksanaanya yaitu Peraturan Pemerintah Nomor 9 Tahun 1975 tentang Pencatatan Perkawinan. Disamping aturan tata tertib perkawinan lainnya seperti hukum adat dan agama.

Menurut Undang-undang Perkawinan yaitu UU No. 1 Tahun 1974 dalam Pasal 1 menyatakan bahwa "Perkawinan sebagai ikatan lahir dan batin antara seorang wanita dengan seorang pria sebagai suami isteri dengan tujuan membentuk keluarga yang bahagia dan kekal berdasarkan Ketuhanan Yang Maha Esa"

Di dalam Undang-Undang Nomor 1 Tahun 1974 tentang perkawinan dinyatakan bahwa suatu perkawinan adalah sah bila dilakukan menurut hukum masing-masing agamanya, kepercayaannya dan disamping itu setiap perkawinan harus dicatat menurut peraturan perundang-undangan yang berlaku, dalam hal ini adalah Undang-Undang No.32 Tahun 1954 tentang pencatatan nikah, talak dan rujuk dan peraturan pemerintah No.9 Tahun 1975 tentang pelaksanaan Undang-undang perkawinan.

Suatu perkawinan dianggap sah bila telah memenuhi persyaratan dan ketentuan, baik itu berdasarkan peraturan perundang-undangan maupun berdasarkan aturan agama dan kepercayaan dari yang melakukan perkawinan.

Perkawinan dan agama mempunyai hubungan yang erat dan tidak terpisahkan. Hampir semua agama mengatur masalah perkawinan yang pada dasarnya selalu menginginkan perkawinan di antara pria dan wanita yang satu agama. Hal ini dapat dipahami, karena agama merupakan dasar yang utama dan sangat penting dalam menentukan keberhasilan kehidupan rumah tangga seseorang.

Setelah berlakunya Undang-Undang Nomor 1 Tahun 1974, maka perkawinan beda agama tidak dibenarkan dan tidak sah. Hukum perkawinan beda agama atau biasa juga dikenal dengan perkawinan lintas agama selalu menjadi polemik yang cukup kontroversial dalam masyarakat, khususnya Negara yang memiliki berbagai macam penduduk dengan

Vol. 20 No. 1 Mei 2018 
agama yang berbeda-beda. Walaupun demikian dalam kenyataannya masih ada terjadi perkawinan ini di tengah-tengah masyarakat yang dilakukan secara tertutup atau secara terang-terangan dengan melangsungkan perkawinan tersebut di luar negeri dan setelah itu kembali ke Indonesia dan mencatatkannya di Kantor Catatan Sipil seolah-olah perkawinan tersebut sama dengan perkawinan campuran sebagaimana dimaksud dalam Pasal 57 Undang-Undang Perkawinan Nomor 1 Tahun 1974.

Kemudian ketentuan Pasal 2 Undang-Undang Nomor 1 Tahun 1974 menyebutkan bahwa: "Perkawinan adalah sah, apabila dilakukan menurut hukum masing-masing agamanya dan kepercayaannya". Apabila diperhatikan Undang-Undang Nomor 1 Tahun 1974, tidak terdapat pasal yang mengatur perkawinan beda agama. Bahkan di dalam Pasal 8 huruf $\mathrm{f}$ disebutkan bahwa "Perkawinan dilarang antara dua orang yang mempunyai hubungan yang oleh agamanya atau peraturan lain berlaku, dilarang kawin".

Di dalam pasal 57 Undang-undang No.1 Tahun 1974 mengatur perkawinan campuran antara dua orang yang tunduk pada dua hukum yang berlainan. Pasal ini menyangkut perbedaan warga Negara dan tidak secara tegas menyebutkan adanya perkawinan beda agama.

Apapun alasan yang dikemukakan dan bagaimanapun cara yang dilakukan, maka sesuai dengan Pasal 2 ayat (1) Undang-Undang Perkawinan Nomor 1 Tahun 1974, perkawinan beda agama tidak dibenarkan dan tidak sah. Oleh karena itu, tidak membawa konsekuensi hukum yang sah terhadap segala akibat yang timbul dari perkawinan tersebut.

Konsekuensi hukum yang dimaksud disini adalah segala akibat yang timbul dari perkawinan, seperti calon ahli waris atau anak yang dilahirkan dari perkawinan tersebut akan menemukan suatu permasalahan baik secara hukum Maupun agama yang dianut oleh anak tersebut nantinya.

Di dalam Pasal 43 ayat (1) Undang-Undang Nomor 1 Tahun 1974 menentukan bahwa; "Anak yang dilahirkan di luar perkawinan mempunyai hubungan perdata dengan ibunya dan keluarga ibunya serta dengan laki-laki sebagai ayahnya yang dapat dibuktikan berdasarkan ilmu pengetahuan dan teknologi dan atau alat bukti lain menurut hukum mempunyai hubungan darah, termasuk hubungan perdata dengan ayahnya."

Perkawinan beda agama bukanlah hal yang baru. Indonesia merupakan Negara mayoritas muslim terbanyak diseluruh dunia, namun masih saja perkawinan beda agama di Indonesia juga sering terjadi khususnya antara agama islam dan agama kristen. Seperti yang terjadi dikalangan selebriti Jamal Mirdad dengan Lidya Kandaw, Nia Zulkarnain dengan Ari Sihasale, Yuni Shara dengan Henry Siahaan, Kalima dengan Deddy Corbuzier dan masih banyak lagi.

Perkawinan beda agama masih merupakan persoalan yang peka dinegeri kita. Sebab boleh dikatakan semua agama tidaklah menginginkan terjadinya perkawinan beda agama. Tapi perkembangan zaman memunculkan perkawinan beda agama yang seharusnya tidak diinginkan dan semakin hari semakin sering terjadi. Oleh karena itu perkawinan beda agama dipandang sebagai salah satu faktor yang menghambat seseorang mendapatkan waris dari orang tuanya tetapi acapkali ditemukan dalam satu keluarga, sesama saudara kandung memeluk agama yang berbeda. Mereka hidup rukun tanpa terusik oleh perbedaan keyakinan itu. Namun dalam praktik, kerukunan itu sering terganggu oleh masalah pembagian harta warisan. Perbedaan agama telah menjadi penghalang.

Vol. 20 No. 1 Mei 2018 
Menurut ajaran Islam, salah satu hijab hak waris adalah perbedaan agama. Seorang anak yang menganut agama lain di luar agama orang tuanya yang Muslim dengan sendirinya terhalang untuk mendapatkan waris.

\section{B. ANALISIS DAN PEMBAHASAN}

\section{Hak Mewaris Anak Yang Lahir Dari Perkawinan Beda Agama}

Dalam uraian latar belakang penulisan telah dijelaskan secara singkat apa yang dimaksud dengan perkawinan beda agama. Perkawinan beda agama tidak diatur dalam Undang-Undang Nomor 1 Tahun 1974. Walapun demikian pada pokoknya perkawinan beda agama ini tidak diinginkan oleh pembentuk undang-undang.

Hal tersebut terlihat dari isi Pasal 1 mengatakan, perkawinan bertujuan membentuk keluarga (rumah tangga) yang diberkahi dan kekal berdasarkan Ketuhanan Yang Maha Esa dilakukan menurut hukum masing-masing agamanya. Kemudian didalam Pasal 2 ayat (1) juga ditentukan bahwa perkawinan adalah sah apabila dilakukan menurut hukum masing masing agamanya.

Dengan demikian dapat diketahui bahwa suatu perkawinan yang dilakukan bertentangan dengan ketentuan agama dan kepercayaan, maka perkawinan tersebut tidak sah dan tidak mempunyai akibat hukum. Namun apabila ketentuan tersebut dihubungkan dengan pasal-pasal lain yang terdapat dalam Undang-Undang Perkawinan Nomor 1 Tahun 1974 Tentang perkawinan dan Peraturan Pemerintah Nomor 9 Tahun 1975 ternyata mengandung ketidakjelasan mengenai saat sahnya perkawinan kaitannya dengan pencatatannya.

Dalam penjelasan Pasal 2 Undang-Undang Perkawinan, tidak ada perkawinan di luar hukum agama dan kepercayaan masing-masing. Sesuai dengan UUD 1945, maka perkawinan yang memenuhi ketentuan Pasal 2 ayat (1) adalah sah apabila dilakukan menurut hukum masing masing agama dan kepercayaannya meskipun tidak dicatatkan dengan kata lain untuk sahnya suatu perkawinan hanya ada satu syarat yaitu jika dilakukan menurut ketentuan hukum agama, sedangkan pencatatan perkawinan menurut Pasal 2 ayat (3) tidak lain hanyalah syarat administratif saja.

Dengan demikian pada satu pihak ditentukan bahwa pencatatan perkawinan hanyalah bersifat administratif saja, sedangkan di lain pihak menyatakan bahwa pencatatan perkawinan tidak hanya syarat administratif saja akan tetapi merupakan syarat lain yang menentukan sahnya suatu perkawinan yaitu hukum agama.

Secara umum menurut penulis perkawinan beda agama sangat berpotensi menimbulkan persoalan-persolan hukum tersendiri, baik kepada pasangan suami isteri itu sendiri maupun kepada pihak luar/ketiga. Persoalan tersebut salah satunya adalah mengenai hak kewarisan antara suami isteri dan anak-anaknya seandainya keabsahan perkawinan pasangan beda agama tidak dipersoalkan dan dianggap perkawinan tersebut adalah sah termasuk status anak-anaknya juga dianggap sah, namun hak kewarisan diantara mereka tidak ada karena perbedaan agama menggugurkan hak saling mewaris.

Menurut penulis bila persoalan kewarisan dilihat dari aspek keadilan, maka larangan perkawinan beda agama jelas lebih melindungi hak kewarisan masing-masing. Hal ini disebabkan anak-anak tidak mungkin beragama kembar, karena agama adalah masalah 
keyakinan. Konsekuensinya anak-anak hanya akan seagama dengan salah satu dari kedua orang tuanya dan atau bisa menganut agama lain yang dianut oleh kedua orang tuanya.

Apabila ada anak yang seagama dengan bapak atau ibunya saja, maka ia hanya akan mendapatkan hak kewarisan dari bapak atau ibunya saja yang seagama, sehingga ia akan berhadapan dengan saudaranya yang beda agama. Hal ini karena menimbulkan masalah keadilan, yaitu anak yang seagama akan mendapatkan hak kewarisan sedangkan saudara kandungnya yang beda agama tidak mendapatkan hak kewarisan.

Di atas telah disinggung mengenai keturunan, yaitu hubungan darah antara bapak, ibu dan anak-anaknya. Jadi antara bapak dan ibu serta anak ada hubungan biologis. Sedangkan anak-anak lainnya, yakni anak yang mempunyai ibu dan bapak, yang tidak terikat dengan perkawinan, dinamakan anak tidak sah atau anak luar kawin.

Penentuan hubungan perdata sangat penting bagi status anak luar kawin karena salah satu akibat adanya hubungan perdata tersebut adalah hak mewaris dari anak luar kawin terhadap kedua orang tua biologisnya. Mewaris adalah menggantikan hak dan kewajiban seseorang yang meninggal. Adapun yang digantikan adalah hak dan kewajiban dalam bidang hukum kekayaan, artinya hak dan kewajiban yang dapat dinilai dengan uang.

Baru-baru ini Undang-Undang Nomor 1 Tahun 1974 Pasal 43 ayat (1) dijudicial review oleh Macicha Mokhtar, sehingga keluarlah putusan Mahkamah Konstitusi pada tanggal 17 Februari 2012 menjadi: Anak yang dilahirkan di luar perkawinan mempunyai hubungan pedata dengan ibunya dan keluarga ibunya serta dengan laki-laki sebagai ayahnya yang dapat dibuktikan berdasarkan ilmu pengetahuan dan teknologi dan atau alat bukti lain menurut hukum mempunyai hubungan darah, termasuk hubungan perdata dengan ayahnya.

Namun ketentuan didalam Pasal 100 Kompilasi Hukum Islam (KHI) yang menyebutkan bahwa anak yang lahir di luar perkawinan, hanya mempunyai hubungan nasab dengan ibunya dan keluarga ibunya. Yang dimaksud anak di luar nikah disini adalah anak yang lahir melalui pernikahan tetapi belum diakui negara karena tidak dicatatkan, seperti nikah siri. Memang secara hukum, tidak ada istilah anak hasil hubungan zina, yang ada hanya anak di luar nikah. Tetapi anak hasil zina disini adalah anak tanpa nikah sehingga tidak tergolong anak luar nikah seperti yang dimaksudkan putusan MK tersebut.

Dengan demikian berdasarkan Pasal 43 ayat (1) Undang-Undang Perkawinan, maka anak yang lahir di luar perkawinan hanya berhak mewaris dari ibunya namun tidak menutup kemungkinan seorang anak juga berhak mewaris dari ayahnya dengan cara membuktikan apa benar mempunyai hubungan darah dengan laki-laki yang dimaksud sebagai ayahnya. Hal ini karena menurut penulis perkawinan beda agama adalah perkawinan yang tidak sah, sehingga status anak yang lahir dari perkawinan tersebut adalah tidak sah sehingga dapat dipersamakan dengan anak luar kawin, maka dia pun hanya mempunyai hubungan perdata dengan ibunya saja sehingga hanya berhak mewaris dari ibunya. Namun anak luar kawin tetap bisa mewaris apabila bapak biologisnya mengakuinya. 
Hak waris aktif anak-anak luar kawin diatur dalam Pasal 862 sampai dengan Pasal 866 dan Pasal 873 ayat (1) KUH Perdata. Kedudukan anak luar kawin diakui sebenarnya sama dengan kedudukan ahli waris lainnya. Dengan demikian anak luar kawin diakui juga mempunyai hak-hak yang dimiliki seorang ahli waris, hal yang membedakan hanyalah bagian yang ia terima tidak sama dengan anak sah. Besarnya bagian warisan dari anakanak luar kawin tergantung dari derajat hubungan kekeluargaan dari pada ahli waris yang sah.

Dalam kasus perkawinan beda agama, sepanjang tidak ada pihak ketiga yang memperkarakan keabsahan perkawinan mereka, maka anak-anak mereka menjadi ahli waris yang sah. Tetapi apabila ada pihak ketiga yang memperkarakan ke Pengadilan dan dapat membuktikan bahwa perkawinan mereka tidak sah, maka anak-anak mereka hanya dapat mewaris dari ibunya saja sebagai ibunya dan tidak berhak mewaris kepada bapaknya.

Berkaitan dengan ahli waris, berdasarkan ketentuan Pasal 832 KUHPerdata : "Menurut undang-undang yang berhak menjadi ahli waris ialah para keluarga sedarah, baik yang sah menurut undang-undang maupun yang diluar perkawinan, dari suami atau isteri yang hidup terlama menurut peraturan-peraturan berikut ini”.

Jadi asas dalam Pasal 832 KUHPerdata bahwa menurut undang-undang, untuk dapat mewaris orang harus mempunyai hubungan darah dengan pewaris. Hubungan darah tersebut dapat sah atau luar kawin, baik melalui garis ibu maupun garis bapak. Hubungan darah yang sah adalah hubungan yang ditimbulkan sebagai akibat dari perkawinan yang sah. Perkawinan yang sah maksudnya adalah sah menurut ketentuan hukum yang berlaku, yaitu Pasal 2 Undang-Undang Nomor 1 Tahun 1974 tentang Perkawinan.

Selanjutnya ahli waris menurut Pasal 171 huruf c Kompilasi Hukum Islam (KHI) menyatakan bahwa : "Ahli waris adalah orang yang pada saat meninggal dunia mempunyai hubungan darah atau hubungan perkawinan dengan pewaris, beragama Islam dan tidak terhalang oleh hukum untuk menjadi ahli waris".

Pengertian beragama Islam dalam hal ini adalah sebagaimana diatur dalam Pasal 172 Kompilasi Hukum Islam (KHI) yang menyatakan bahwa : "Ahli waris dipandang beragama islam dilihat dari Kartu Identitas atau pengakuan atau amalan atau kesaksian, sedangkan bagi bayi yang baru lahir atau anak yang belum dewasa, beragama menurut ayahnya atau lingkungannya".

Menurut penulis berdasarkan pengertian ahli waris menurut Pasal 832 KUH Perdata dan Pasal 171 huruf c Kompilasi Hukum Islam (KHI), terdapat persamaan dan perbedaan diantara keduanya. Persamaannya adalah adanya unsur hubungan darah dan hubungan perkawinan, sedangkan perbedaannya adalah adanya unsur agama.

Unsur agama yang dimaksud menurut ketentuan Pasal 171 huruf c Kompilasi Hukum Islam (KHI) adalah yang berhak menjadi ahli waris (yang beragama Islam) harus beragama Islam (seagama dengan pewaris). Sehingga dengan demikian apabila antara pewaris dengan ahli waris tidak seagama (biasanya ahli warisnya non-muslim), maka tidak saling mewaris atau bukan ahli waris dari pewaris yang beragama Islam.

Vol. 20 No. 1 Mei 2018 
Oleh karenanya menurut penulis dilihat dari sudut pandang Hukum Waris Islam, maka anak yang lahir dari perkawinan beda agama tidak mempunyai hak untuk mendapatkan harta waris apabila tidak seagama dengan pewaris yang dalam hal ini pewaris beragama Islam. Namun demikian apabila pewaris tidak beragama Islam (nonmuslim), sedangkan ahli warisnya tidak seagama dengan pewaris (nonmuslim), maka tetap berhak mewaris. Hal tersebut didasarkan pada hubungan darah antara pewaris dengan ahli waris, sebagaimana diatur dalam ketentuan Pasal 832 KUH Perdata maupun Pasal 171 huruf c Kompilasi Hukum Islam (KHI).

\section{Faktor Yang Menghambat Hak Mewaris Anak yang Lahir Dari Perkawinan Beda Agama}

Masyarakat Indonesia tergolong heterogen dalam segala aspek dengan beragam budaya, suku dan agama yang dianut masyarakatnya. Keseluruhan agama yang ada memiliki tata aturan sendiri sendiri baik secara vertikal maupun horizontal termasuk tata cara perkawinannya. Hukum perkawinan yang berlaku bagi setiap agama tersebut berbeda satu sama lain akan tetapi tidak saling bertentangan. Walaupun demikian setiap agama mengharuskan umatnya untuk kawin dengan yang seagama.

Perkawinan dan agama mempunyai hubungan yang erat, di mana agama akan sangat berperan dalam pembentukan rumah tangga. Undang-Undang perkawinan Nomor 1 Tahun 1974 sangat erat hubungannya dengan agama, karena perkawinan menurut Pasal 1 Undang-Undang tersebut, "ialah ikatan lahir batin antara seorang pria dengan seorang wanita sebagai suami istri dengan tujuan membentuk keluarga (rumah tangga) yang berbahagia dan kekal berdasarkan Ketuhanan Yang Maha Esa".

Perkataan "Ketuhanan Yang Maha Esa" yang disebut dalam pembukaan dan dirumuskan dalam Batang Tubuh UUD 1945 Pasal 29 ayat (1) dicantumkan dibawah Bab Agama, maka Ketuhanan Yang Maha Esa dalam UUD 1945 itu adalah Ketuhanan Yang Maha Esa menurut agama, bukan Ketuhanan menurut pengertian lain di luar hukum agama.

Di atas telah diuraikan bahwa perkawinan beda agama adalah perkawinan yang tidak sah, karenanya apabila perkawinan tersebut tetap berlangsung dan dari hasil perkawinannya dikaruniai anak maka sesungguhnya anak hasil perkawinan tersebut adalah tidak sah, karena perkawinannya sendiri tidak sah. Selanjutnya bagaimana dengan kedudukan anak tersebut?

Anak yang sah adalah anak yang dilahirkan dalam atau sebagai akibat perkawinan yang sah, hal tersebut ditegaskan dalam Pasal 42 Undang-Undang Perkawinan tersebut bermakna bahwa hanya dari perkawinan yang sah saja yang dapat mempunyai anak yang sah. Ini adalah sama dengan apa yang ditetapkan dalam Pasal 250 Kitab Undang- Undang Hukum Perdata, yang secara lebih tegas mengatakan bahwa setiap anak yang dilahirkan atau ditumbuhkan sepanjang perkawinan memperoleh suami sebagai bapaknya. Demikian juga dengan ketentuan Pasal 99 Kompilasi Hukum Islam yang menyatakan bahwa anak yang sah adalah anak yang dilahirkan dalam atau akibat perkawinan yang sah. Ketentuanketentuan yang disebutkan tadi memberikan apa yang dinamakan suatu "persangkaan undang-undang." 
Dalam Kitab Undang-Undang Hukum Perdata, anak luar kawin dapat diakui bapaknya, pengakuan ini menimbulkan hubungan perdata antara anak dengan bapak yang mengakuinya, tetapi tidak menimbulkan hubungan dengan keluarga bapak yang mengakuinya itu. Namun demikian Dalam Kitab Undang-Undang Hukum Perdata Belanda yang baru (sejak tahun 1956), ada ketentuan yang menyatakan bahwa ibu dari anak itu tidak perlu mengakui dan secara otomatis sudah timbul hubungan perdata antara ibu dan anak, jadi hanya bapak saja yang harus mengakui anaknya.

Dalam perkawinan beda agama, masalah kewarisan sangat berpotensi menimbulkan konflik dalam keluarga. Sehingga dapat menjadi hambatan hak waris anak yang lahir dalam perkawinan beda agama.

Hukum warisan di Indonesia sejak dahulu sampai saat ini masih beraneka ragam bentuknya, masing-masing golongan penduduk tunduk kepada aturan-aturan hukum yang berlaku kepadanya sesuai dengan ketentuan Pasal 163 IS (indische staatsregeling) jo. Pasal 131 IS. Golongan penduduk tersebut terdiri dari :

1. Golongan Eropa \& yang dipersamakan dengan mereka;

2. Golongan Timur Asing Tionghoa \& Non Tionghoa;

\section{Golongan Bumi Putera.}

Berdasarkan peraturan Perundang-undangan R. I. UU No. 62 / 1958 \& Keppers No. 240 / 1957 pembagian golongan penduduk seperti diatas telah dihapuskan tentang hukum waris ini dapat dilihat di dalam Hukum Kewarisan Islam, Hukum Adat \& Kitab UndangUndang Hukum Perdata (KUH Perdata). Ketiga sistem hukum ini memiliki karakteristik \& ciri khas masing-masing mengakibatkan terjadinya perbedaan antara yang satu dengan lainnya. Namun demikian apabila berbicara persoalan hukum waris, maka tidak terlepas dari 3 (tiga) unsur pokok yaitu ; adanya harta peninggalan atau kekayaan pewaris yang disebut warisan, adanya pewaris yaitu orang yang menguasai atau memiliki harta warisan \& adanya ahli waris yaitu orang yang menerima pengalihan atau penerusan atau pembagian harta warisan.

Tidak selamanya mendengar dan menguraikan tentang hukum waris, kita teringat kepada seorang yang telah meninggal dunia dan meninggalkan harta pusaka yang langsung dapat dibagi-bagikan kepada seluruh ahli waris untuk dapat memiliki dan dikuasai secara bebas, tetapi adakalanya terjadi pewaris dalam arti penunjukan atau penerusan harta kekayaan pewaris sejak pewaris masih hidup.

Untuk bidang hukum waris adat misalnya, pluralisme itu terjadi pada umumnya disebabkan oleh adanya pengaruh dari susunan kekeluargaan kekerabatan yang dianut di Indonesia. Adapun susunan tersebut antara lain :

1. Pertalian keturunan menurut garis laki-laki (Patrilineal), sebagai contoh : Misalnya : Batak, Bali, Ambon;

2. Pertalian keturunan menurut garis perempuan (matrilineal), sebagai contoh: Minangkabau, Kerinci (Jambi), Semendo (Sumetera Selatan);

3. Pertalian keturunan menurut garis Ibu dan bapak (Parental/Bilateral), misalnya : Melayu, Bugis, Jawa, Kalimantan (Dayak). 
Disamping itu, dalam hal sistem pewarisanya pun bermacam-bermacam pula , yakni terbagi atas 3 ( tiga ) bagian yaitu:

1. Sistem Pewarisan Individual, misalnya : Pada susunan kekeluargaan bilateral (Jawa) dan susunan kekeluargaan patrilineal (Batak);

2. Sistem Pewarisan Kolektif, misalnya: Harta pusaka tinggi di Minangkabau, Tanah dati di Ambon;

3. Sistem Pewarisan Mayorat, misalnya : di Bali dan Lampung.

Demikianlah corak khas dari hukum waris bangsa Indonesia yang selama ini berlaku, dimana terdapat beberapa titik persamaannya. Hal tersebut menjadi hambatan hak mewaris anak yang lahir dari perkawinan beda agama, karena tentunya masing- masing pihak akan menggunakan hukum waris agamanya.

Sebagaimana diketahui bersama bahwa hukum kewarisan Islam yang berlaku adalah Hukum Faraidh, yaitu menurut istilah bahasa ialah takdir (qadar / ketentuan dan pada syara adalah bagian yang diqadarkan / ditentukan bagi waris) dengan demikian faraidh adalah khusus mengenai bagian ahli waris yang telah ditentukan besar kecilnya oleh syara'.

Demikian faraidh diatur antara lain tentang tata cara pembagian Harta Warisan, besarnya bagian antara anak laki-laki dengan anak perempuan, pengadilan mana yang berwenang memeriksa dan memutuskan sengketa warisan. Untuk itu Allah menurunkan ayat Al-Qur'an yang artinya : "Bagi orang laki-laki ada hak bagian dari harta peninggalan Ibu Bapak dan kerabatnya, dan bagi orang wanita ada hak bagian ( pula ) dari harta peninggalan Ibu Bapak dan kerabatnya, baik sedikit ataupun banyak menurut bagian yang telah ditetapkan".

Bagian harta peninggalan si pewaris yang akan dinikmati oleh para ahli waris baik anak laki maupun anak perempuan kemudian ditetapkan oleh Allah didalam Al-Qur'an yang artinya sebagai berikut : "Allah mensyariatkan bagimu (tentang pembagian pusaka) untuk anakmu, yaitu bagian seorang anak laki-laki sama dengan bagian dua orang anak perempuan ".

Jadi jelaslah bahwa pembagian harta warisan (pusaka) menurut syariat Islam tunduk kepada yang telah ditetapkan oleh Allah SWT yakni bagian seorang anak laki- laki sama dengan bagian 2 (dua) orang anak perempuan atau 2 (dua) berbanding 1 (satu).

Selanjutnya menurut ketentuan Pasal 171 huruf A Kompilasi Hukum Islam (KHI) menyatakan : Hukum kewarisan adalah hukum yang mengatur tentang pemindahan hak milik harta peninggalan (Tirkah) pewaris, menentukan siapa yang berhak menjadi ahli waris dan berapa bagiannya masing-masing.

Kemudian Pasal 176 Bab III Kompilasi Hukum Islam (KHI) menjelaskan tentang : Besar bagian untuk seorang anak perempuan adalah setengah (1/2) bagian; bila 2 (dua orang atau lebih mereka bersama-sama mendapatkan dua pertiga 2/3) bagian; dan apabila anak perempuan bersama-bersama dengan anak laki-laki maka bagiannya adalah 2 (dua) berbanding 1 (satu) dengan anak perempuan. 
Selanjutnya Pasal 183 Kompilasi Hukum Islam (KHI) menyatakan : "Para ahli waris dapat bersepakat melakukan perdamaian dalam pembagian harta warisan, setelah masingmasing menyadari bagiannya".

Dari uraian tertera diatas, nampak bahwa antara apa yang telah ditetapkan didalam ayat Al-Qur'an dengan yang terdapat dalam Kompilasi Hukum Islam (KHI) khususnya mengenai besarnya bagian antara anak laki-laki dengan anak perempuan dalam pembagian harta warisan yang ditinggalkan oleh si pewaris adalah sama yakni 2 (dua) berbanding 1 (satu). Berhubung oleh karena Al-Qur'an dan hadist Nabi hukumnya wajib dan merupakan pegangan / pedoman bagi seluruh umat Islam dimuka bumi ini, maka ketentuan-ketentuan pembagian harta warisan (pusaka) inipun secara optimis pula haruslah ditaati dan dipatuhi.

Dari keterangan diatas, menurut penulis jelaslah ditegaskan bahwa tentang warisan supaya dilaksanakan sesuai dengan ketetapan yang telah ditentukan dan memberikan pahala surga bagi yang mematuhi dan mengancam dengan azab api neraka terhadap yang menolaknya dan mengikarinya. Dengan perkataan lain Islam telah mengatur dengan pasti tentang hukum waris yang berlaku bagi pemeluknya.

Didalam hukum waris Islam menganut prinsip kewarisan individu bilateral, bukan kolektif maupun mayorat. Sehingga dengan demikian Hukum Waris Islam tidak membatasi pewaris itu dari pihak bapak ataupun ibu saja dan para ahli warispun dengan demikian tidak pula terbatas pada pihak laki-laki ataupun pihak perempuan saja.

Ada tiga yang menjadi penghalang warisan atau yang dikenal dengan istilah mawani', yaitu adalah pembunuhan, beda agama dan perbudakan. Dalam mawani' yang kedua, yaitu beda agama, pengertiannya adalah bila seorang muwarrist (orang yang meninggal dunia dan memiliki harta untuk dibagi waris) dan ahli waris berbeda agama, maka tidak terjadi pewarisan antara kedua. Beda agama di sini maksudnya salah satunya muslim dan satunya lagi bukan muslim.

Sebagaimana telah penulis jelaskan diatas bahwa di Indonesia masih terdapat pluralisme Hukum Waris, maka dalam pembahasan mengenai hak mewaris anak yang lahir pada perkawinan beda agama juga akan dibahas dari sudut pandang Hukum Waris Barat (KUH Perdata). Berbicara mengenal hukum waris barat yang dimaksud adalah sebagaimana diatur dalam KUH Perdata (BW) yang menganut sistem individual, dimana harta peninggalan pewaris yang telah wafat diadakan pembagian. Ketentuan aturan ini berlaku kepada warga negara Indonesia keturunan asing seperti eropa, china, bahkan keturunan arab dan lainnya yang tidak lagi berpegang teguh pada ajaran agamanya.

Sampai saat ini aturan tentang hukum waris barat tetap dipertahankan walaupun beberapa peraturan yang terdapat di dalam KUH Perdata dinyatakan tidak berlaku lagi, seperti hukum perkawainan menurut KUH Perdata telah dicabut dengan berlakunya UU No. 1/1974, tentang perkawinan yang secara unifikasi berlaku bagi semua warga negara.

Pokok hukum waris barat dapat dilihat pada pasal 1066 KUHPerdata yang menyatakan: 
1. Dalam hal seorang mempunyai hak atas sebagian dari sekumpulan harta benda, seorang itu tidak dipaksa membiarkan harta bendanya itu tetap di bagi-bagi diantara orangorang yang bersama-sama berhak atasnya;

2. Pembagian harta benda ini selalu dituntut meskipun ada suatu perjanjian yang bertentangan dengan itu;

3. Dapat diperjanjikan, bahwa pembagian harta benda itu dipertangguhkan selama waktu tertentu;

4. Perjanjian semacam ini hanya dapat berlaku selama lima tahun tetapi dapat diadakan lagi , kalau tenggang lima tahun itu telah lalu.

Jadi hukum waris barat menganut sistem begitu pewaris wafat, harta warisan langsung dibagi-bagikan kepada para ahli waris. Setiap ahli waris dapat menuntut agar harta peninggalan (pusaka) yang belum dibagi segera dibagikan, walaupun ada perjanjian yang bertentang dengan itu, kemungkinan untuk menahan atau menangguhkan pembagian harta warisan itu disebabkan satu dan lain hal dapat berlaku atas kesepakatan para ahli waris, tetapi tidak boleh lewat waktu lima tahun kecuali dalam keadaan luar biasa waktu lima tahun dapat diperpanjang dengan suatu perpanjangan baru.

Sedangkan ahli waris hanya terdiri dari dua jenis yaitu :

1. Ahli waris menurut UU disebut jugs ahli waris tanpa wasiat atau ahli waris ab intestato, yaitu :

1) Suami atau isteri (duda atau janda) dari pewaris (simati);

2) Keluarga sedarah yang sah dari pewaris;

3) Keluarga sedarah alami dari pewaris.

2. Ahli waris menurut surat wasiat (ahli waris testamentair), yaitu semua orang yang oleh pewaris diangkat dengan surat wasiat untuk menjadi ahli warisnya.

Berkaitan dengan hak mewaris anak yang lahir dalam perkawinan beda agama, seperti yang telah penulis jelaskan pada pembahasan sebelumnya bahwa berdasarkan pengertian ahli waris menurut Pasal 832 KUHPerdata dan Pasal 171 huruf c Kompilasi Hukum Islam (KHI), terdapat persamaan dan perbedaan diantara keduanya. Persamaannya adalah adanya unsur hubungan darah dan hubungan perkawinan, sedangkan perbedaannya adalah adanya unsur agama.

Unsur agama yang dimaksud menurut ketentuan Pasal 171 huruf c Kompilasi Hukum Islam (KHI) adalah yang berhak menjadi ahli waris (yang beragama Islam) harus beragama Islam (seagama dengan pewaris). Sehingga dengan demikian apabila antara pewaris dengan ahli waris tidak seagama (biasanya ahli warisnya non-muslim), maka tidak saling mewaris atau bukan ahli waris dari pewaris yang beragama Islam.

Berdasarkan Undang-Undang Nomor 7 Tahun 1989 tentang Peradilan Agama, keluarga muslim pihak dapat memilih hukum apa yang akan diberlakukan dalam pembagian warisan bagi mereka. Klausul itu tercantum pada bagian penjelasan umum Undang-Undang Nomor 7 Tahun 1989 tentang Peradilan Agama, disebutkan bahwa

Vol. 20 No. 1 Mei 2018 
'Para pihak sebelum berperkara dapat mempertimbangkan untuk memilih hukum apa yang dipergunakan dalam pembagian warisan'.

Berdasarkan klausul ini pula, para ahli waris yang beragama Islam bisa memilih sengketa waris mereka menggunakan hukum perdata atau hukum Islam. Akibatnya, banyak terjadi gugatan antar ahli waris karena ketidaksepakatan tentang hukum yang mereka pakai dalam membagi harta warisan.

Dengan demikian, oleh karena masih terdapat pluralisme hukum waris, maka hal tersebut menjadi hambatan hak mewaris anak yang lahir dalam perkawinan beda agama. Ketentuan hukum mana yang berlaku, hal ini karena masing-masing pihak (pewaris maupun ahli waris) tentunya tetap berpegang teguh pada ketentuan hukum dimana dia tunduk khususnya hukum agama yang dianut.

Hambatan tersebut menurut penulis sebenarnya dapat teratasi, mengacu pada ketentuan Fatwa Majelis Ulama Indonesia (MUI) Nomor : 5/MUNAS VII/9/2005 tentang Kewarisan Beda Agama, yang menetapkan bahwa :

1. Hukum waris Islam tidak memberikan hak saling mewaris antar orang-orang yang beda agama (antara muslim dengan non-muslim);

2. Pemberian harta antar orang berbeda agama hanya dapat dilakukan dalam bentuk hibah, wasiat dan hadiah.

Meskipun Hukum waris Islam tidak memberikan hak saling mewaris antar orangorang yang beda agama (antara muslim dengan non-muslim), tetapi terdapat ketentuan yang menyatakan bahwa pemberian harta antar orang berbeda agamanya dapat dilakukan dalam bentuk hibah, wasiat dan hadiah. Sehingga hak waris anak yang lahir dalam perkawinan beda agama tetap bisa mendapatkan harta dari orang tuanya yang beda agama dalam bentuk hibah, wasiat dan hadiah.

Namun meskipun anak yang lahir dalam perkawinan beda agama tetap bisa mendapatkan harta dari orang tuanya yang beda agama salah satunya dalam bentuk wasiat, bukan merupakan wasiat wajibah sebagaimana diatur dalam Pasal 209 Kompilasi Hukum Islam (KHI). Oleh karena ketentuan tersebut sangat jelas hanya berlaku bagi orang tua angkat dan anak angkat.

Menurut penulis pada akhirnya masalah kewarisan khususnya mengenai hak waris anak yang lahir dalam perkawinan beda agama, dikembalikan kepada masyarakat khususnya pihak-pihak yang bersengketa. Apakah akan mengacu atau tunduk pada hukum agamanya atau hukum lainnya (Hukum Perdata Barat/KUH Perdata atau Hukum Adat), karena hal tersebut memang dimungkinkan oleh ketentuan hukum yang berlaku yaitu Undang-Undang Nomor 7 Tahun 1989 tentang Peradilan Agama, dalam Penjelasan Umum disebutkan bahwa para pihak sebelum berperkara dapat mempertimbangkan untuk memilih hukum apa yang dipergunakan dalam pembagian warisan. Sehingga selama masih terdapat pluralisme hukum waris, maka hal tersebut menjadi hambatan hak mewaris anak yang lahir dalam perkawinan beda agama. Ketentuan hukum mana yang berlaku, hal ini karena masing-masing pihak (pewaris maupun ahli waris) tentunya tetap berpegang teguh pada ketentuan hukum dimana dia tunduk khususnya hukum agama yang dianut.

Vol. 20 No. 1 Mei 2018 


\section{PENUTUP}

Perkawinan beda agama tidak mempunyai hak untuk mendapatkan harta waris apabila tidak seagama dengan pewaris yang dalam hal ini pewaris beragama Islam. Namun demikian apabila pewaris tidak beragama Islam (non-muslim), sedangkan ahli warisnya tidak seagama dengan pewaris (non-muslim), maka tetap berhak mewaris. Hal tersebut didasarkan pada hubungan darah antara pewaris dengan ahli waris, sebagaimana diatur dalam ketentuan Pasal 832 KUHPerdata maupun Pasal 171 huruf c Kompilasi Hukum Islam (KHI).

Faktor yang menghambat hak mewaris anak yang lahir dari perkawinan beda agama adalah belum adanya unifikasi yang mengatur tentang waris karena dalam kenyataannya masih terdapat pluralisme hukum waris, sehingga dalam menyelesaikan masalah hak mewaris anak yang lahir dari perkawinan beda agama masing-masing pihak tunduk pada hukum yang berbeda yaitu berdasarkan hukum agama atau adat. Namun demikian berkaitan dengan hal tersebut, hak mewaris anak yang lahir dari perkawinan beda agama dapat diatasi dengan dikeluarkannya Fatwa Munas VII Majelis Ulama Indonesia (MUI) Nomor 5/MUNAS-VII/MUI/9/2005 yang menyatakan bahwa pemberian harta kepada orang yang berbeda agama hanya dapat dilakukan dalam bentuk hibah, hadiah dan wasiat.

\section{DAFTAR PUSTAKA}

Alimuddin, 2014.Pembuktian Anak Dalam Hukum Acara Peradilan Agama, Bandung, Penerbit Nuansa Aulia.

Ashshofa Burhan. 2007, “Metodologi Penelitian Hukum”, Rineke Cipta, Jakarta.

Haries, Akhmad. 2010. Hukum Kewarisan Islam, Samarinda: P3M STAIN Samarinda.

Jimly Asshidiqie dan Ali Safaat, 2006, Teori Hans Kelsen Tentang Hukum, Sekretariat Jenderal dan Kepaniteraan Mahkamah Konstitusi Republik Indonesia, Jakarta.

M. syamsuddin. 2007, “Operasionalisasi Penelitian Hukum”, Rajawali Press, Jakarta.

Mardalis. 2008. Metode Penelitian Suatu Pendekatan Proposal. Jakarta: Bumi Aksara.

Mulyadi, 2008. Hukum Perkawinan Indonesia, Badan Penerbit Universitas Diponegoro Semarang.

Soerjono Soekanto, Pengantar Penelitian Hukum, IU-Press, Jakarta 2002.

Soerjono Soekanto \& Sri Mamudji, 2007, "Penelitian Hukum Normatif Suatu Tinjauan Singkat”, Rajagrafindo Persada, Jakarta.

Sugiyono. (2008.) Metode Penelitian Kuantitatif, Kualitatif dan R\&D. Bandung : Alfabeta.

Syahruddin Nawi, 2014. "Penelitian Hukum Normatif dan Penelitian Hukum Empiris". Penerbit PT. Umitoha Ukhuwah Grafika, Makassar.

Syamsuddin Pasamai, 2007. "Metodologi Penelitian dan Penulisan Karya Ilmiah Hukum; Suatu Pengetahuan Praktis”. Umitoha Ukhuwah Grafika. Makassar. 